\title{
The Impact of the Leadership in Energy and Environmental Design Accredited Professional (LEED-AP) Credential on Prime/General Contractor Employees
}

\author{
Richard D. Bruce, Ph.D., LEED-AP, Richard J. Gebken, Ph.D., \\ and Shawn D. Strong, Ph.D. \\ Missouri State University \\ Springfield, MO
}

\begin{abstract}
The Leadership in Energy and Environmental Design (LEED) accreditation is quickly becoming one of the most popular professional designations available to members of the design and building construction community. The purpose of this article was to determine the impact the LEED-AP designation has had on Prime/General Contractor Employees. The researchers analyzed 9,060 responses from LEED-AP's. LEED-AP Prime/General Contractor Employees reported that while the LEED-AP credential has not impacted their salary or promotional opportunities it has increased their ability to perform their job, increased their prestige, increased their responsibility, and increased confidence in their abilities.
\end{abstract}

Key Words: Accreditation, Certification, LEED, Construction Education

\section{Introduction}

Leadership in Energy and Environmental Design (LEED) is one of several different green building guidelines being used in today's building industry. Arguably the most well-known of the current models, the use of LEED as a building certification tool has grown exponentially over the past few years (USGBC, 2008). Much of this growth can be attributed to the increase in perceived value for LEED buildings (Friess, 2008; Howard, 2008), the availability of educational opportunities about the benefits of LEED (Fusscas and Muldavin, 2006; Kats, 2004; Wilson, 1999), and the development of governmental mandates requiring LEED certification, or related requirements, for public projects (ENR, 2005; Sodoma, 2008)

Coupled with the growth of LEED as a green building guideline in the United States, there has been a parallel groundswell of interest in LEED credentialing for individuals. Since the inception of the LEED Accredited Professional (LEED-AP) designation in 2001, a total of 62,000 individuals have received their credentials indicating an understanding of green building practices (GBCI, 2008a). Originally part of the U.S. Green Building Council's (USGBC) effort to increase sustainable buildings, an independent organization, the Green Building Certification Institute (GBCI), now oversees the LEED-AP program.

As in many other sectors (e.g., healthcare, automotive repair, accounting, etc.), obtaining a credential is one way to show proficiency within a given area of specialization. LEED-AP credential holders are often viewed as valuable assets in terms of knowledge and experience while potentially giving companies involved in the building industry an advantage in certain markets (GBCI, 2008b). Unfortunately, little information outside the claims of the USGBC and the GBCI exist to document the value, whether real or perceived, for obtaining a LEED-AP credential. This study addresses this lack of data by surveying LEED-APs for their experience on the impact of obtaining the LEED-AP credential. The authors' intent is to explore whether or not there is a statistically significant difference between the impact of LEED-AP credentials for prime/general contractors and LEED-APs working for other entities. The answer to this question will therefore help individuals make a more informed decision about what actual benefits there are when obtaining a LEED-AP or similar credential. 


\section{Literature Review}

A good starting point in understanding the importance and impact of professional credentials is to examine the definition of professional certification. Bratton and Hildebrand (1980, p. 23), in their study of technology certification in education, define certification as, "the process by which a professional organization or an independent external agency recognizes the competence of individual practitioners." Similarly, Summerfield (1991) defines certification for health, leisure and movement professionals as the process of proving qualifications through education, experience, and general examination components; however, she also differentiates certifications from licensures, registrations, and accreditations. In this study, the LEED-AP credential is considered a professional certification, despite the "Accredited Professional" terminology developed by USGBC and GBCI. The following few paragraphs will review the existing literature on the perceptions of professional certification both in and outside of the building industry. Lastly, a summary of key findings which influenced the design of this study will be presented.

The authors found many examples of research addressing the value of certification outside the building industry. In fact, in areas such as nursing, information technology, and automotive repair there are extensive studies exploring the value of various professional certifications. In regard to nursing, both Stromborg et al. (2005) and Mee \& Carey (2001) found that salaries and/or incentives for obtaining a professional certification can be sizable. Similarly, research involving information technology certification has found significant benefits including employer recognition, distinction among peers, and salary increases in the range of 10 to 20 percent for a single certification (Brandel, 2001). Finally, in the area of automotive repair, Yemaneab (1998) found that employers favored hiring certified technicians almost three-to-one and consumers perceived a higher level of credibility when certified technicians were utilized over non-certified technicians.

While less extensive than in many of the areas described above, the building industry is increasingly examining the value of certifications in its profession. Izenson (2002) describes several different certifications available for architects, engineers, and constructors including certification by the American Institute of Architects (AIA), the Design-Build Institute of America (DBIA), and the Tilt-Up Concrete Association (TCA). She states, "Those who gain certification benefit by increased respect and recognition in the industry or profession, improved opportunity for upward mobility, increased professional credibility and higher self-esteem" (Izenson, 2002, p. 22). More recently, Bruce et al. (2008) examined the perceived value of the American Institute of Constructors' (AIC) Certified Professional Constructor (CPC) credential. The authors found that the CPC credential holders perceived many benefits including increased recognition, opportunities, responsibilities, and prestige. In addition, the research also found that CPCs without a bachelor's degree felt strongest that their salary was increased as a result of certification.

The existing literature shows that many occupational areas have examined individual certification in greater detail than the building industry. Healthcare, information technology, and automotive repair are three examples where lessons learned from previous studies can shed some light on different ways individuals can associate value with a particular certification. Increased credibility, recognition/prestige, and improved customer satisfaction are just some of the observations in other industries that could be examined with respect to the LEED-AP credential.

\section{Methodology}

Using Roberts (2005) Certified Research Administrators Survey as a guide, the researchers developed the Perceptions of LEED-AP Survey using an online survey building tool named Survey Monkey. The survey included a total of 35 questions about the impact of the certification on the respondent's career, support they received from their employers, difficulty of the exam, and demographic information.

This study's primary research question asked if LEED-APs working for Prime/General Contractors valued the credential as much as employees of other organizations. To answer this question, the researchers focused their attention on survey question 1,2, 3, 4, and 33. Question 1 asked if the respondent was at least 18 years old and a LEED-AP. If they responded with a yes they advanced, if no, their survey was terminated. Question 2 asked respondents how the LEED-AP credential has impacted their career in regard to recognition, professional 
opportunities, salary, promotion opportunity, job responsibilities, and prestige. Respondents were given six response options to these statements including strongly agree, agree, no difference, disagree, strongly disagree, and not applicable. Question 3 asked respondents if they felt more knowledgeable as a result of becoming accredited. Question 4 asked LEED-APs if they felt more confident in their ability to do their work. Respondents could choose yes, no, or no difference for questions three and four. Question 33 asked respondents to select all classifications that reflected the business of their organization including public owner, private owner, architect/engineer, prime/general contractor, subcontractor, university, and other.

\section{Results}

As mentioned previously, at the time of this study there were 62,000 total LEED-APs in the World. The researchers were able to retrieve 46,332 of their e-mails from the GBCI website. Of the 46,332 total original e-mails that were sent out, 4,555 (9.8\%) were returned to the researcher as undeliverable. Thus 41,477 LEED-APs were successfully contacted. Upon closing, 9,060 of the 41,777 (22\%) successfully contacted LEED-APs had responded. If one compares the total number of responses $(9,060)$ to the entire population $(62,000)$, this study achieved a success rate of $14.6 \%$.

Table 1 shows the frequency of the different organization types with architect/engineers as the most popular (39\%). As one can see, the total frequency $(10,695)$ exceeds the total number of survey respondents $(9,060)$. This is due to the survey question having the "Select all that apply" option.

\section{Table 1}

\section{What is the classification of the organization where you are currently employed?}

\begin{tabular}{llcc} 
& & Frequency & Percent \\
\hline Valid & Public Owner & 435 & 4 \\
& Private Owner & 2958 & 28 \\
& Architect/Engineer & 4210 & 39 \\
& Prime/General Contractor & 1742 & 16 \\
& Subcontractor & 279 & 3 \\
& University & 198 & 2 \\
& Other & 873 & 8 \\
Total & & 10695 & $100 \%$ \\
\hline
\end{tabular}

Tables 2-9 address how the respondent felt in regard to the impact the accreditation has had on their career. Table 2 shows that $58 \%$ of Prime/General Contractors and $64 \%$ of all other organization classifications either agreed or strongly agreed that others more fully recognized their abilities to perform their job as a result of gaining the LEEDAP credential. Table 3 shows that $51.3 \%$ of Prime/General Contractors and all others agreed or strongly agreed that the credential increased their professional opportunities for improvement. Table 4 shows that nearly $85 \%$ of both Prime/General Contractors and all other classifications felt as though the credential did not have an impact on their salary. However, table 5 indicates that $41 \%$ of Prime/General Contractors and $37.9 \%$ of all other classifications agree or strongly agree that the credential has increased their promotional opportunities. Table 6 shows that more than half of both groups (56.8\% of Prime/General Contractors and 57.6\% of all other classifications) enjoy more responsibility. 
Table 2

How has being a LEED-AP impacted your career in terms of having others more fully recognize your abilities to perform your job?

\begin{tabular}{lllccc}
\hline & & & $\begin{array}{c}\text { Prime/General } \\
\text { Contractors }\end{array}$ & Others & Total \\
\hline Valid & Strongly Agree & Count & $156(9 \%)$ & $718(11 \%)$ & $874(11 \%)$ \\
& Agree & Count & $849(49 \%)$ & $3454(53 \%)$ & $4303(52 \%)$ \\
& No Difference & Count & $675(39 \%)$ & $2171(33 \%)$ & $2846(34 \%)$ \\
& Disagree & Count & $26(1.5 \%)$ & $91(1.4 \%)$ & $117(1.4 \%)$ \\
& Strongly Disagree & Count & $24(1.3 \%)$ & $76(1.1 \%)$ & $100(1.2 \%)$ \\
& N/A & Count & $5(0.2 \%)$ & $32(0.5 \%)$ & $37(0.4 \%)$ \\
Total & & Count & $1735(100 \%)$ & $6542(100 \%)$ & $8277(100 \%)$ \\
\hline
\end{tabular}

Table 3

How has being a LEED-AP impacted your career in terms of increasing your professional opportunities for contributions?

\begin{tabular}{lllccc}
\hline & & $\begin{array}{c}\text { Prime/General } \\
\text { Contractors }\end{array}$ & Others & Total \\
\hline Valid & Strongly Agree & Count & $220(12.7 \%)$ & $858(13.1 \%)$ & $1078(13 \%)$ \\
& Agree & Count & $669(38.6 \%)$ & $2496(38.2 \%)$ & $3165(38.3 \%)$ \\
& No Difference & Count & $751(43.3 \%)$ & $2827(43.3 \%)$ & $3578(43.3 \%)$ \\
& Disagree & Count & $45(2.6 \%)$ & $196(3 \%)$ & $241(2.9 \%)$ \\
& Strongly Disagree & Count & $33(1.9 \%)$ & $96(1.5 \%)$ & $129(1.6 \%)$ \\
& N/A & Count & $15(0.9 \%)$ & $62(.9 \%)$ & $77(0.9 \%)$ \\
Total & & Count & $1733(100 \%)$ & $6535(100 \%)$ & $8268(100 \%)$ \\
\hline
\end{tabular}

Table 4

How has being a LEED-AP impacted your career in terms of increasing your salary?

\begin{tabular}{lllccc}
\hline & & Prime/General & Other & Total \\
\hline Valid & Strongly Agree & Count & $40(2.3 \%)$ & $183(2.8 \%)$ & $223(2.7 \%)$ \\
& Agree & Count & $234(13.5 \%)$ & $839(12.8 \%)$ & $1073(13 \%)$ \\
& No Difference & Count & $1255(72.3 \%)$ & $4613(70.5 \%)$ & $5868(70.9 \%)$ \\
& Disagree & Count & $108(6.2 \%)$ & $411(6.3 \%)$ & $519(6.3 \%)$ \\
& Strongly Disagree & Count & $79(4.6 \%)$ & $362(5.5 \%)$ & $441(5.3 \%)$ \\
& N/A & Count & $20(1.2 \%)$ & $134(2 \%)$ & $154(1.9 \%)$ \\
Total & & Count & $1736(100.0 \%)$ & $6542(100.0 \%)$ & $8278(100.0 \%)$ \\
\hline
\end{tabular}

Table 5 
How has being a LEED-AP impacted your career in terms of increasing your promotion opportunities?

\begin{tabular}{|c|c|c|c|c|c|}
\hline & & & $\begin{array}{c}\text { Prime/General } \\
\text { Contractors }\end{array}$ & Others & Total \\
\hline \multirow[t]{6}{*}{ Valid } & Strongly Agree & Count & $71(4.1 \%)$ & $288(4.4 \%)$ & $359(4.3 \%)$ \\
\hline & Agree & Count & $641(36.9 \%)$ & $2188(33.5 \%)$ & $2829(34.3 \%)$ \\
\hline & No Difference & Count & $899(51.8 \%)$ & $3435(52.7 \%)$ & $4334(52.5 \%)$ \\
\hline & Disagree & Count & $71(4.1 \%)$ & $281(4.3 \%)$ & $352(4.3 \%)$ \\
\hline & Strongly Disagree & Count & $37(2.1 \%)$ & $174(2.7 \%)$ & $211(2.6 \%)$ \\
\hline & N/A & Count & $14(0.8 \%)$ & $157(2.4 \%)$ & $171(2.1 \%)$ \\
\hline Total & & Count & $1736(100 \%)$ & $6523(100 \%)$ & $8256(100 \%)$ \\
\hline
\end{tabular}

Table 6

How has being a LEED-AP impacted your career in terms of increasing your job responsibilities?

\begin{tabular}{lllccc}
\hline & & Prime/General & Cothers & Total \\
\hline Valid & Strongly Agree & Count & $186(10.7 \%)$ & $718(11.0 \%)$ & $904(10.9 \%)$ \\
& Agree & Count & $801(46.1 \%)$ & $3048(46.6 \%)$ & $3849(46.5 \%)$ \\
& No Difference & Count & $675(38.9 \%)$ & $2422(37.0 \%)$ & $3097(37.4 \%)$ \\
& Disagree & Count & $46(2.6 \%)$ & $155(2.4 \%)$ & $201(2.4 \%)$ \\
& Strongly Disagree & Count & $17(1 \%)$ & $102(1.6 \%)$ & $119(1.4 \%)$ \\
& N/A & Count & $11(.6 \%)$ & $94(1.4 \%)$ & $105(1.3 \%)$ \\
Total & & Count & $1736(100 \%)$ & $6539(100 \%)$ & $8275(100 \%)$ \\
\hline
\end{tabular}

Tables 7-9 address the impact of accreditation on the LEED-AP's prestige within and outside their organization. Table 7 shows that over $72 \%$ of Prime/General Contractors and $67 \%$ of all other classifications felt that the accreditation increased their prestige among their superiors. Table 8 illustrates that over $72 \%$ of Prime/General Contractors and $69 \%$ of all others felt that the accreditation increased their prestige with peers inside their organization. Table 9 shows that over 74\% Prime/General Contractors and 77\% of all others felt that the LEED designation increased their prestige among individuals outside of their organization.

Table 7

How has being a LEED-AP impacted your career in terms of increasing your prestige among superiors within your organization?

\begin{tabular}{lllccc}
\hline & & \multicolumn{2}{c}{$\begin{array}{c}\text { Prime/General } \\
\text { Contractors }\end{array}$} & Others & Total \\
\hline Valid & Strongly Agree & Count & $204(11.8 \%)$ & $740(11.3 \%)$ & $944(11.4 \%)$ \\
& Agree & Count & $1056(60.8 \%)$ & $3676(56.3 \%)$ & $4732(57.3 \%)$ \\
& No Difference & Count & $418(24.1 \%)$ & $1768(27.1 \%)$ & $2186(26.5 \%)$
\end{tabular}




\begin{tabular}{|c|c|c|c|c|c|}
\hline & Disagree & Count & $28(1.6 \%)$ & $123(1.9 \%)$ & $151(1.8 \%)$ \\
\hline & Strongly Disagree & Count & $15(0.9 \%)$ & $72(1.1 \%)$ & $87(1.1 \%)$ \\
\hline & N/A & Count & $11(0.6 \%)$ & $152(2.3 \%)$ & $163(2 \%)$ \\
\hline Total & & Count & $1736(100 \%)$ & $6531(100 \%)$ & $8263(100 \%)$ \\
\hline
\end{tabular}

Table 8

How has being a LEED-AP impacted your career in terms of increasing your prestige among individuals within your organization?

\begin{tabular}{lllccc}
\hline & & Prime/General & Contractors & Others & Total \\
\hline Valid & Strongly Agree & Count & $179(10.3 \%)$ & $661(10.1 \%)$ & $840(10.2 \%)$ \\
& Agree & Count & $1088(62.7 \%)$ & $3871(59.3 \%)$ & $4959(60 \%)$ \\
& No Difference & Count & $417(24 \%)$ & $1748(26.8 \%)$ & $2165(26.2 \%)$ \\
& Disagree & Count & $32(1.8 \%)$ & $106(1.6 \%)$ & $138(1.7 \%)$ \\
& Strongly Disagree & Count & $17(1 \%)$ & $63(1 \%)$ & $80(1 \%)$ \\
& N/A & Count & $5(0.3 \%)$ & $82(1.3 \%)$ & $87(1.1 \%)$ \\
Total & & Count & $1736(100 \%)$ & $6531(100 \%)$ & $8269(100 \%)$ \\
\hline
\end{tabular}

Table 9

How has being a LEED-AP impacted your career in terms of increasing your prestige among individuals outside your organization?

\begin{tabular}{lllccc}
\hline & & Prime/General & Contractors & Total \\
\hline Valid & Strongly Agree & Count & $198(11.4 \%)$ & $876(13.4 \%)$ & $1074(13 \%)$ \\
& Agree & Count & $1089(62.7 \%)$ & $4153(63.6 \%)$ & $5242(63.4 \%)$ \\
& No Difference & Count & $414(23.8 \%)$ & $1361(20.8 \%)$ & $1775(21.5 \%)$ \\
& Disagree & Count & $22(1.3 \%)$ & $82(1.3 \%)$ & $104(1.3 \%)$ \\
& Strongly Disagree & Count & $10(.6 \%)$ & $40(0.6 \%)$ & $50(0.6 \%)$ \\
& N/A & Count & $0(0 \%)$ & $20(0.3 \%)$ & $20(0.2 \%)$ \\
Total & & Count & $1736(100 \%)$ & $6532(100 \%)$ & $8265(100 \%)$ \\
\hline
\end{tabular}

Tables 10-11 show the results concerning the impact of accreditation on the respondents' knowledge and confidence to do their work. Table 10 shows that over $85 \%$ of Prime/General Contractors and over $82 \%$ of all other classifications felt more knowledgeable as a result of becoming accredited. Table 11 shows that over $45 \%$ of Prime/General Contractors and over $50 \%$ of all other classifications felt more confident in their ability to do their work.

Table 10

Do you feel more knowledgeable as a result of becoming accredited? 


\begin{tabular}{|c|c|c|c|c|c|}
\hline & & & $\begin{array}{c}\text { Prime/General } \\
\text { Contractors }\end{array}$ & Others & Total \\
\hline \multirow[t]{3}{*}{ Valid } & Yes & Count & $1480(85.2 \%)$ & $5380(82.2 \%)$ & $6860(82.8 \%)$ \\
\hline & No & Count & $130(7.5 \%)$ & $586(9 \%)$ & $716(8.6 \%)$ \\
\hline & No Difference & Count & $127(7.3 \%)$ & $578(8.8 \%)$ & $705(8.5 \%)$ \\
\hline Total & & Count & $1737(100 \%)$ & $6544(100 \%)$ & $8281(100 \%)$ \\
\hline
\end{tabular}

Table 11

Do you feel more confident in your ability to do your work?

\begin{tabular}{lllccc}
\hline & & $\begin{array}{c}\text { Prime/General } \\
\text { Contractors }\end{array}$ & Others & Total \\
\hline Valid & Yes & Count & $788(45.5 \%)$ & $3357(51.4 \%)$ & $4145(50.1 \%)$ \\
& No & Count & $404(23.3 \%)$ & $1334(20.4 \%)$ & $1738(21 \%)$ \\
& No Difference & Count & $541(31.2 \%)$ & $1842(28.2 \%)$ & $2383(28.8 \%)$ \\
Total & & Count & $1733(100 \%)$ & $6533(100 \%)$ & $8266(100 \%)$ \\
\hline
\end{tabular}

The analysis of variance showed a significant difference (.05 alpha) between the two groups in regard to questions $2 \mathrm{a}(.000 \mathrm{sig}, \mathrm{F}=14.245)$, question $2 \mathrm{~d}(.000, \mathrm{~F}=13.994)$, question $2 \mathrm{f}(.000, \mathrm{~F}=23.033)$, and question $2 \mathrm{~g}(.003$, $\mathrm{F}=8.985)$. The means of these two groups, per question, can be compared in Table 12.

Table 12

\section{Means Comparison of Impact of Credential by Organization Classification}

\begin{tabular}{lcc}
\hline & $\begin{array}{c}\text { Prime/General } \\
\text { Contractors }\end{array}$ & Others \\
\hline Q2a Having others more fully recognize your abilities to perform your job & 3.62 & 3.70 \\
Q2b Increasing your professional opportunities for contributions & 3.55 & 3.56 \\
Q2c Increasing your salary & 2.99 & 2.95 \\
Q2d Increasing your promotion opportunities & 3.34 & 3.26 \\
Q2e Increasing your job responsibilities & 3.61 & 3.59 \\
Q2f Increasing your prestige among superiors within your organization & 3.79 & 3.68 \\
Q2g Increasing your prestige among individuals within your organization & 3.79 & 3.72 \\
Q2h Increasing your prestige among individuals outside your organization & 3.83 & 3.87 \\
\hline
\end{tabular}

\section{Discussion}

As mentioned in the introduction, little information outside the claims of the USGBC and the GBCI exist to document the value, whether real or perceived, for obtaining the LEED-AP credential. This study addressed this lack of data. The results indicate that while many LEED-APs have not seen an impact on salary or promotional opportunities, they do feel as though the credential is positively impacting their recognition from others, their professional opportunities, their job responsibilities, prestige, acquisition of knowledge, and confidence in their ability to do their work. These findings may be used by the GBCI and USGBC to support their own findings. They may also be used by individuals in the design and construction industry looking to set themselves apart from their peers. 
Another conclusion is that LEED-APs working for Prime/General Contractor firms are reaping the same benefits as those working for all other types of organizations. They may even be benefitting more than the largest organization type (architects/engineers) as shown by the analysis of variance. This should encourage more individuals, including superintendents and project managers working for Prime/General Contractors, to pursue the credential. It may also encourage subcontractors and suppliers to do the same.

Possible areas of further study include comparing the perceived value of holding the various construction credentials including the Certified Professional Constructor (CPC), Project Management Professional (PMP), and other construction-related credentials. Another study could compare the perceptions of constructors holding these credentials and those in the industry who do not hold certifications.

\section{References}

Brandel, M. (2001). The Top Certifications. Computerworld. 35(20), 63.

Bratton, B., and Hildebrand, M. (1980). Plain Talk about Professional Certification. Instructional Innovator. 25(9), $22-24$.

Bruce, R., Sauer, A., and McCandless, D. (2008). The Perceived Value of Constructor Certification to Certified Professional Constructors. The American Professional Constructor. 32(1), 9-16.

ENR. (2005). State Legislators Take 'LEED' With New Green Building Law. ENR: Engineering News-Record. 254(16), 12-12.

Friess, S. (2008). "Las Vegas bets on environmentalism." In: USA Today.

Fusscas, A., and Muldavin, S. (2006). Preliminary Analysis of Existing Case Study Databases Relevant to Green Buildings. Green Building Finance Consortium, San Rafael, CA

GBCI. (2008a). GBCI: About GBCI. URL http://www.gbci.org/DisplayPage.aspx?CMSPageID=19 (Visited October 29, 2008).

GBCI. (2008b). GBCI: Professional Credentials. URL http://www.gbci.org/DisplayPage.aspx?CMSPageID=28 (Visited October 29, 2008).

Howard, H. (2008). Starwood Is Going Green With a New Hotel Chain. New York Times, 2.

Izenson, K. (2002). Continuing Education and Certification Grows Throughout the Industry. Design Cost Data.

Kats, G. (2004). What are the Costs and Financial Benefits of Green Buildings? Capital E, Washington, D.C.

Mee, C. L., and Carey, K. W. (2001). Nursing 2001 salary survey. Nursing. 31(3), 44-47.

Sodoma, B. (2008). What Stays in Las Vegas Is Green. Planning. 74(2), 40-43.

Stromborg, M. F., Niebuhr, B., Prevost, S., Fabrey, L., Muenzen, P., Spence, C., Towers, J., and Valentine, W. (2005). Specialty Certification. Nursing Management. 36(5), 36-46.

Summerfield, L. M. (1991). "Credentialing in the Health, Leisure, and Movement Professions. Trends and Issues Paper No. 5." ERIC Clearinghouse on Teacher Education.

USGBC. (2008). "YOU_SGBC." U.S. Green Building Council, Washington, D.C. 
Wilson, A. (1999). Building Green on a Budget. Environmental Building News, 8(5).

Yemaneab, T. (1998). Employer' Perception of Automotive Service Excellece (ASE) Certification Benefits, University of Minnesota, Minneapolis, MN. 